\title{
Pendidikan Multikulturalisme Di Era Modern (Dialektika Kritis Pendidikan Islam Monokotomik)
}

\author{
Jasmani \\ STAIN Palangka Raya \\ jasmani33355@gmail.com
}

\begin{abstract}
Monokotomic education is the educational system construction of the plenary which is capable of integration educational value of domain-oriented humanitarian and religious by a nature.The education system also implies an attitude of valuing differences in values, norms, culture and tradition (Multiculturalism) as well as of the religious aspect of pluralism as a consequence of the Muslims. Therefore, there needs to be a paradigm in education it is necessary to elaborate on the elements of cultural pluriformity become construction between the wisdom or community - read the culture. It is intended as an attempt to construct a more civilized society structure, harmonious, and prosperous with cache while respecting cultural differences. Konstruks education is believed to be supporting the formation of communities of multiculturalism and pluralism in this modern era; where the whole community with all the elemental sued for bear's fate and interdependence together for the creation of a lasting peace. Therefore, education (Islamic) multiculturalism with the paradigm of monokotomic need to be constructed which will later put forward positional egalitarian culture system at all, so it's able to eliminate the superiority-inferiority between one culture and other cultures.
\end{abstract}

Keyword: education (Islam), Integralistik, Monokotomic, and multiculturalism

\section{A. Pendahuluan}

Di dalam tulisan ini, penulis mencoba untuk membangun wacana pendidikan holistik yang orientasi pemikirannya memfokuskan pada konstruks pendidikan Islam sebagai suatu sistem pendidikan paripurna di era modern ini. Hal ini bisa dilihat dari dua domain yang berbeda yaitu domain filosofis dan domain historik. Pada domain yang pertama, pendidikan Islam mempunyai landasan ontologik yang holistik mencakup fakta fisis (orientasi kemanusiaan dan kealaman) dan metafisis (orientasi ketuhanan dan wahyuistik). Dari sisi epistemologik pun, pendidikan Islam tidak hanya mengandalkan aspek rasionalistas sebagai medium utama dalam mengkonstruks anatomi pendidikan Islam, namun ia juga melekatkan pada sisi normatif sumber utama Islam yaitu alQur'an dan al-Hadist. Dengan alur inilah, aksiologik pendidikan Islam lebih mengutamakan integralisasi nilai antara sistem pendidikan kemanusiaan dan kealamanan (ilmu-ilmu alam dan humaniora) dengan pendidikan keagamaan. 
Sedangkan domain yang kedua yaitu domain historik yang secara konklutif-postulatif telah mengurai kegemilangan sistem pendidikan Islam. Salah satunya contoh pada skala kelembagaan adalah peran pesantren yang telah berhasil mengakulturasikan Islam dengan budaya lokal dan secara sosio-politik ia juga memainkan peranan penting dalam membangun masyarakat Indonesia sejak awal kedatangan Islam di Indonesia hingga sekarang. ${ }^{1}$ Ada pula pakar lain yaitu John Walbridge yang menjelaskan bahwa:

The madrasa system, with its rationalistic curriculum, prospered for some six centuries, dominating religious education in the Islamic world and deeply influencing parallel systems of education. In the nineteenth century, it abruptly collided with the forces of modernism -colonial administrators, Christian missionaries, Muslim reformers, and Muslim revivalists. Where it survived at all, it was usually a shadow of its former self, reduced in wealth and prestige and often warped by the conflicting demands of modernism and its own past. Islamic education was swept up in a debate embracing European colonial administrators and intellectuals and parents in virtually every Islamic country. It was a debate that the madrasa professors were ill equipped to participate in. ${ }^{2}$

Deskripsi historikal tersebut mengisyaratkan adanya konstruksi pendidikan yang dilihat dari aspek inside maupun outside memiliki polaritas yang sempurna, sehingga hal ini bisa dijadikan indikator bahwa pendidikan Islam mampu menjadi sistem pendidikan yang "tak terkalahkan" dengan sistem pendidikan lainnya. Di sisi yang lain, kompetensi sistem pendidikan yang seperti itulah mampu melahirkan ilmuwan-ilmuwan terkenal seperti al-Khawarizmi (Algorismus) dan Ibn al-Haitam (al-Hazen) yang di kenal sebagai ahli matematika dan astronomi; Ibn Rusyd (Averroes) dan Ibn Sina (Avicena) dikenal sebagai ahli kedokteran; alKhazini, al-Khurasani, al-Razi dan Ibn Sina adalah penyumbang terbesar terhadap ilmu fisika dan teknologi. Karya dari para ilmuwan muslim ini sampai sekarang masih tetap menjadi rujukan para ilmuwan dunia di bidangnya masing-masing. ${ }^{3}$

${ }^{1}$ Lihat detailnya dalam Suparjo, Socio-Cultural Strategies of Pesantren to Construct Society: A Socio-Historical Perspective, dalam Ibda' Jurnal Studi Islam dan Budaya Vol. 4, No. 1 Januari-Juni 2006, 103-120.

${ }^{2}$ John Walbridge, God and Logic in Islam:The Caliphate of Reason, (Cambridge: Cambrige University Press, 2011), 153.

${ }^{3}$ Sukarji \& Umiarso, Manajemen dalam Pendidikan Islam: Konstruksi Teoritis dalam Menemukan Kebermaknaan Pengelolaan Pendidikan Islam, (Jakarta: Mitra Wacana Media, 2014), 
Bahkan ia juga mampu menyatukan berbagai budaya atau juga tradisi keilmuan lain, salah satu contohnya adalah pandangan dan sikap keilmuan di zaman nabi Muhammad yang memposisikan ilmu secara paralel tersebut menyebabkan eksplorasi terhadap ilmu selain "ilmu agama" sudah mulai dilakukan meskipun dalam kadar yang sangat sederhana. Bahkan nabi Muhammad sendiri tidak pernah mengajarkan kepada pengikutnya yang beriman dan bertaqwa untuk menjauhi dunia yang merupakan media dalam menggapai kesempurnaan hidup.

Nilai-nilai tersebut sangat tampak seakan-akan menjadi klausul normatif pada saat Islam lahir pada pertengahan pertama abad ke-7 M. Di mana bangsa Arab dikelilingi oleh bangsa-bangsa yang memiliki kebudayaan tinggi dan megah, seperti Persia, Romawi, Yunani dan India. Walaupun pada masa pra Islam di Arab telah ada "era" yang dikenal dengan zaman Jahiliah" ${ }^{4}$ di mana pada era ini sudah ada semacam ilmu yang kemudian sedikit banyak mempengaruhi terhadap perkembangan ilmu agama Islam, terutama ilmu bahasa Arab. Maka sebagai masyarakat yang baru lahir, Islam tidak serta merta menjauhi peradaban diluar dirinya yang notabene non-Islam. Dengan ada kebudayaan dan peradaban tinggi

1; lihat juga dalam Harun Nasution, Islam Ditinjau dari Berbagai Aspeknya, (Jakarta: UI Press, 1979).

${ }^{4}$ Jahiliah di sini bukan berarti tidak berilmu sama sekali, sebab pada dasarnya mereka memiliki kemampuan dalam banyak hal. Mereka mampu mengadakan perjalanan jauh untuk berdagang, mengadakan hubungan dan berurusan dengan pembesar-pembesar Romawi dan Persia. Jahiliah di sini dimaksudkan bahwa masyarakat Arab senantiasa berpegang teguh kepada tradisi nenek moyangnya, yang berarti mereka telah berpaling dari ajaran yang pernah diajarkan oleh nabi Ibrahim dan nabi Isma'il kepada kemusyrikan yang penuh dengan takhayul khurafat dengan penyembahan kepada berhala yang mereka buat sendiri. Sudah jelas bahwa kepercayaan mereka itu akan mempengaruhi sikap hidupnya sendiri. Selain itu, kondisi iklim yang panas dan kering pun sangat mempengaruhi konstitusi kejiwaannya, yakni membentuk watak yang keras karena terus berjuang melawan alamnya hingga dapat menyesuaikan diri. Kelemahan akan mengakibatkan kehancuran hidup yang fatal, akan ditelan oleh seleksi alam. Hukum adalah kekuatan dan kekuasaan. Karena itu pula, mereka tidak memiliki kesadaran terhadap sesuatu yang lebih baik. Samsul Nizar (Edit.), Sejarah Pendidikan Islam: Menelusuri Jejak Sejarah Pendidikan Era NabiMuhammad Sampai Indonesia, (Jakarta: Kencana, 2009), 209. Lihat juga dalam Soekarno \& Ahmad Supardi, Sejarah dan Filsafat Pendidikan Islam, (Bandung: Angkasa, 1986), 25-26. Akan tetapi di satu sisi ada juga yang berpendapat bahwa anggapan masa jahiliah merupakan masa pra-Islam yang terdiri dari masyarakat komunal primitif, buta huruf dan bahkan biadab, sudah lama ditinggalkan, hal tersebut disebabkan karena terdapat banyak fakta yang membuktikan bahwa bangsa Arab pra-Islam telah mempunyai suatu sistem sosio-budaya yang maju menurut takaran mereka. Gustave Lebon seorang Orientalis, menyatakan bahwa kemajuan Arab pra-Islam telah sampai ke tingkat yang memungkinkan pengikut-pengikut nabi Muhammad untuk melaksanakan risalah mereka dalam dunia peradaban. lebih detailnya lihat dalam Abd. Halim Soebahar, Wawasan Baru Pendidikan Islam, (Jakarta: Kalam Mulia, 2002), 89. 
tersebut, maka umat Islam mempelajari kebudayaan bangsa-bangsa lain yang lebih maju. Usaha ini tidak pernah ada "counter" dalam literatur doktrin Islam, bahkan usaha konstruktif ini telah dilakukan umat Islam di zaman klasik, khususnya sampai masa dinasti bani Umayah dan mencapai puncak kejayaannya pada masa dinasti Abbasiyah.

Perspektif historik tersebut bisa dijadikan dasar asumsi dari sistem pendidikan Islam yang ada sekarang ini bahwa polaritas sistem pendidikan klasik tersebut pernah menjadi kiblat (rujukan) dari berbagai sistem pendidikan yang pernah ada. Terlebih lagi output dan outcome sistem pendidikan Islam sampai saat ini menjadi tumpuan dan rujukan dari ilmuwan-ilmuwan peradaban lain. Hal ini bisa dikatakan bahwa pendidikan Islam memiliki catatan heroik yang secara signifikan mampu untuk mempengaruhi peradaban-peradaban lain yang ada di dunia pada saat itu (abad-abad pertengahan). Pada saat ini pun, sistem pendidikan Islam juga masih memiliki relevansi dengan peradaban-peradaban modern dengan sistem kelembagaan yang masih ada sebut saja universitas al-Azhar yang ada di Kairo, universitas al-Qarawiyyin di Fez yang dianggap sebagai universitas tandingan bagi universitas al-Azhar, atau universitas Cordova yang ada di Andalusia. $^{5}$

Walaupun demikian, kegemilangan tersebut sampai saat ini masih berada di bawah bayang-bayang peradaban Yunani kuno sebagai sumber ilmu pengetahuan Hellenistik. Di mana tradisi “olah pikir” yang dikembangkan oleh peradaban Yunani kuno dan menghasilkan ilmu pengetahuan ditransmisikan oleh para masyarakat muslim, sehingga terjadi suatu proses akulturasi dan asimilasi budaya; yang oleh kalangan tertentu dikatakan proses ini sangat mencolok di awal pertumbuhan peradaban Islam (abad ke-8 dan 10 M.). ${ }^{6}$ Usaha gigih masyarakat muslim periode awal sampai pada periode pertengahan dalam menerjemahkan

\footnotetext{
${ }^{5}$ Menurut salah satu peneliti sejarah terkemuka yaitu Phillip K. Hitti bahwa kemegahan yang dimiliki oleh universitas Cordova melebihi kemegahan dari Madrasah Nizamiyyah yang berada di Baghdad atau juga universitas al-Azhar Kairo. Lebih detailnya lihat dalam Philip K. Hitti, History of The Arabs: from the Earliest Times to the Present,(New York: St. Martin's Press, 1968), 530.

${ }^{6}$ M. Amin Abdullah, Penerjemahan Karya Klasik, dalam Taufik Abdullah, dkk (Edit.), Ensiklopedi Tematis Dunia Islam: Pemikiran dan Peradaban, (Jilid 4), (Jakarta: Ichtiar Baru Van Hoeve, 2002), 15.
} 
warisan intelektual Yunani ini memiliki peran besar bagi proses kesinambungan mata rantai sejarah peradaban dunia. Khazanah intelektual Yunani kuno yang telah sekian abad "mati suri", dihidupkan kembali oleh budaya Arab-Islam, lalu diterjemahkan ke dalam bahasa Latin dalam alam pikiran Eropa di peralihan Zaman Pertengahan (sekitar abad ke-13 M. sampai 14 M.), untuk selanjutnya diteruskan dan dikembangkan pada abad modern ini. ${ }^{7}$

Secara embrionikal, era perkembangan ilmu pengetahuan teknologi umat Islam telah ada peletakkan dasar yang dimulai di zaman dinasti Umaiyyah -Philip K. Hitti menyatakan bahwa Dinasti Umaiyyah sebagai masa "inkubasi” atau masa tunas bagi perkembangan intelektual Islam-,${ }^{8}$ akan tetapi sangat maju dan berkembang pesat di zaman dinasti Abbasiyah. Pada masa dinasti Umaiyyah juga sudah ada seorang Masarjawaih ahli fisika beragama Yahudi yang telah menerjemahkan buku-buku kedokteran. Juga disiplin ilmu astrologi dan kimia sudah diterjemahkan ke dalam bahasa Arab. ${ }^{9}$ Tradisi intelektualitas ini kemudian berlanjut pada dinasti Abbasiyah yang memusatkan perhatiannya pada perkembangan peradaban umat Islam, sehingga masa dinasti ini disebut sebagai masa pembentukkan dan pengembangan peradaban Islam. ${ }^{10}$ Salah satu contoh adalah Khalifah Harun al-Rasyid (786-809 M.) yang merupakan salah satu dari khalifah dinasti Abbasiyah, dikenal sebagai khalifah yang mencintai seni dan ilmu. Harun al-Rasyid banyak meluangkan waktunya untuk berdiskusi dengan kalangan ilmuwan dan mempunyai apresiasi yang tinggi terhadap seni. Harun alRasyid juga mengembangkan satu akademi Gundishapur yang didirikan oleh Anushirvan pada tahun 555 M. Pada masa pemerintahannya lembaga tersebut dijadikan sebagai pusat pengembangan dan penerjemahan bidang ilmu kedokteran, obat dan falsafah.

${ }^{7}$ Ibid. Untuk melihat sisi kontributif pendidikan Islam terhadap peradaban lain di dunia khususnya pada peradaban Eropa lihat dalam Mehdi Nakosteen, History of Islamic Origins of Western Education, (Colorado: Universitas of Colorado Press, 1964), 61-62; lihat juga dalam Bruce A. Kimball, The Liberal Arts Tradition Documentary History, (Maryland: University Press of America, 2010), 6.

${ }^{8}$ Philip K. Hitti, History of The Arab ... Op. Cit., 240.

${ }^{9}$ Ibid., 25.

${ }^{10}$ Harun Nasution, Islam Ditinjau dari ... Op. Cit., 70. 
Tidak hanya berkutat pada usaha mengembangkan ilmu pengetahuan, implikasi dari polaritas sistem pendidikan Islam adalah munculnya sikap menghargai perbedaan tata nilai, norma, budaya dan tradisi (multikulturalisme) termasuk juga dari aspek agama sebagai konsekuensi dari pandangan pluralisme umat Islam. Hal inilah yang dinyatakan oleh salah satu kalangan bahwa umat Islam dalam pendidikannya mempromosikan pluralisme religius antara muslim dan non muslim. ${ }^{11}$ Sikap multikulturalisme ini secara embrionikal sudah ditanamkan oleh nabi Muhammad ketika ia berada di Madinah bersama sahabatsahabat-Nya yang hijrah dari kota Mekkah. Salah satu contoh dari sikap ini yang tampak dalam diri sahabat adalah seperti Abu Bakar, Umar bin Khattab, Ali bin Abi Thalib dan lain-lainnya yang tidak bisa berdagang, mereka bertani di tanah orang-orang Anshar (orang-orang Madinah), dan hasilnya dibagi dengan pemilik tanah tersebut. ${ }^{12}$

Konstruksi tersebut pada arus dinamika sistem kependidikan Islam tidak lepas dari lingkar doktrin normatif Islam (al-Qur'an dan al-Hadist) serta jangkar spirit monothoisme sebagai dasar utama pengembangan ilmu pengetahuan dan peradaban umat Islam. Dengan sistem pendidikan yang berakar pada nilai-nilai ajaran Islam (al-Qur'an dan al-Hadist) dan diterjemahkan dalam bentuk perilaku pendidikan itulah yang menghasilkan serta mampu mewarnai peradaban dunia sampai saat ini. Dasar pijakan sistem pendidikan Islam secara normatif-doktriner mendorong subjek dan objek pendidikan untuk mengkaji faktasitas ontologik yang integratif untuk perkembangan ilmu pengetahuan. Salah satu nilai normatiftransendental menyatakan bahwa ayat pertama yang turun (surat al-Alaq: 1-5) menegaskan, iqra' (membaca) menjadi dasar utama mengembangkan ilmu pengetahuan dan peradaban manusia. ${ }^{13}$ Ia juga merupakan perintah yang pertama

\footnotetext{
${ }^{11}$ Charlene Tan, Islamic Education and Indoctrination: The Case in Indonesia, (New York: Routledge, 2011), 84.

${ }^{12}$ Ahmad Tafsir, Ilmu Pendidikan Islami, (Bandung: Remaja Rosdakarya, 2012), 87.

${ }^{13}$ Disebutkan dalam Hadist-Hadist shahih, bahwa nabi SAW. mendatangi gua Hira' (Hira' adalah nama sebuah gunung di Mekkah) untuk tujuan beribadah selama beberapa hari. Beliau kembali kepada istrinya -Siti Khadijah- untuk mengambil bekal secukupnya. Hingga pada suatu hari -di dalam gua- beliau dikejutkan oleh kedatangan malaikat membawa wahyu ilahi. Malaikat berkata kepadanya, "Bacalah!" Beliau menjawab, "saya tidak bisa membaca". Perawi mengatakan, bahwa untuk kedua kalinya malaikat memegang nabi dan mengguncangnya hingga nabi
} 
kali turun sebelum perintah-perintah lain; dan ini bisa dimaknai bahwa pendidikan merupakan pilar yang paling utama serta sebagai bekal yang paling mendasar untuk memahami dan mendalami, untuk selanjutnya mengamalkan, perintahperintah yang lain. ${ }^{14}$ Sistem pendidikan Islam demikian inilah (monokotomik) yang mampu melahirkan intelektual muslim yang memiliki karya sangat besar, prestisius dan berpengaruh positif terhadap eksistensi kehidupan manusia.

Sedangkan di Indonesia sendiri sistem pendidikan Islam seperti madrasah, ${ }^{15}$ sekolah Islami, atau Sekolah Tinggi Agama Islam, Institut Agama Islam, atau Universitas Islam telah mulai merengsek dari polaritas paradigma yang dikotomis-sekuleristik ke paradigma monokotomik.-integralistik. Mungkin

kepayahan dan setelah itu dilepaskan. Malaikat berkata lagi kepadanya, "Bacalah!" Nabi menjawab, "saya tidak membaca". Perawi mengatakan, bahwa untuk ketiga kalinya malaikat memegang Nabi dan mengguncang-guncangkannya hingga beliau kepayahan. Setelah itu barulah Nabi mengucapkan apa yang diucapkan oleh malaikat, yaitu surat al-'Alaq (96) ayat 1-5.Para perawi hadist mengatakan, bahwa Nabi SAW. kembali ke rumah Khadijah dalam keadaan gemetar seraya mengatakan, "Selimutilah aku, selimutilah aku". Kemudian mereka menyelimuti beliau hingga rasa takut beliaupun hilang. Setelah itu beliau menceritakan semuanya kepada Khadijah. Lalu beliau berkata, "Aku merasa khawatir terhadap diriku". Khadijah menjawab, "Jangan, bergembiralah! Demi Allah, sesungguhnya Allah tidak akan membuatmu kecewa. Sesungguhnya engkau adalah orang yang menyambung silaturrahmi, benar dalam berkata, menanggung beban, gemar menyuguhi tamu dan gemar menolong orang yang tertimpa bencana".Kemudian Khadijah mengajak beliau menemui Waraqah Ibn Naufal Ibn Abd al-'Uzza (anak paman Khadijah). Beliau adalah pemeluk agama Nasrani di zaman jahilliyah, pandai menulis Arab dan menguasai bahasa Ibrani, serta pernah menulis Injil dalam bahasa Arab dari bahasa aslinya, Ibrani. Beliau seorang yang sudah lanjut usia, dan buta kedua matanya. Khadijah berkata kepadanya, "Hai anak paman, Dengarkanlah apa yang dikatakan anak saudaramu ini!". Waraqah berkata kepada Nabi, "Wahai anak saudaraku, apakah yang engkau saksikan?" Kemudian Nabi SAW. menceritakan apa yang dialaminya kepadanya. Waraqah berkata, "Malaikat Namus inilah yang pernah datang ke nabi Isa. Jika saja aku masih kuat, dan jika saja aku masih hidup tatkala kaummu mengusirmu". Nabi Muhammad SAW. berkata, “Apakah mereka pasti mengusirku?" Waraqah menjawab, "Ya. Tidak seorang pun datang membawa apa yang kamu bawa, melainkan ia akan dimusuhi. Jika aku masih hidup di masa itu, aku akan menolongmu sekuat tenaga". Tetapi tidak lama kemudian ia wafat. Hadist diriwayatkan oleh Imam Ahmad, Bukhari dan Muslim”. Ahmad Musthafa al-Maraghy, Tafsir al-Maraghy, Peterj.: Bahrun Abubakar, (Semarang: Toha Putra, 1985), 325-326. Bandingkan dengan Hamka, Tafsir al-Azhar, Jilid XXX, (Jakarta: Pustaka Panjimas, 1988), 206207. Sayyid Qutb, Fi Zhilal al-Qur'an, Juz 28, (Beirut: Dar al-Fikr, 1967), 612-613. Syaikh Isma'il Haqqiy al-Burusawiy, Tafsir Ruh al-Bayan, Juz 10, (Beirut: Dar al-Fikr, t.t.), 470-471.

${ }^{14}$ Umiarso \& Haris Fathoni Makmur, Pendidikan Islam dan Krisis Moralisme Masyarakat Modern: Membangun Pendidikan Islam Monokhotomik-Holistik, (Yogyakarta: IRCiSoD, 2010), 34.

${ }^{15}$ Kata "madrasah" dalam bahasa Arab adalah bentuk kata "keterangan tempat (zharaf makan) dari akar kata "darasa". Secara harfiah "madrasah" diartikan sebagai tempat belajar para pelajar, atau tempat untuk memberikan pelajaran. Dari akar kata "darasa” juga bisa diturunkan kata "midras" yang mempunyai arti buku yang dipelajari atau tempat belajar; kata "al-midras" juga diartikan sebagai rumah untuk mempelajari kitab Taurat. Abu Luwis al-Yasu'I, al-Munjid Fi al-Lughah Wa al-Munjid Fi al-A'lam, (Bairut: Dar al-Masyriq, tt), 221. 
upaya ini muncul sebagai bentuk keinginan untuk keluar dari jerat hitam cawah candradimuka problematika-problematika akibat dari adanya dikotomi dalam pendidikan Islam, antara lain: pertama, ambivalensi oirientasi pendidikan Islam; Kedua, kesenjangan antara pendidikan Islam dan ajaran Islam; Ketiga, disintegrasi sistem pendidikan Islam hingga saat ini boleh dikatakan kurang terjadi perpaduan (usaha integrasi); dan Keempat, inferioritas para pengasuh lembaga pendidikan Islam. ${ }^{16}$ Lazim apabila bagi masyarakat Islam, mengkaji dan mengembangkan pendidikan Islam untuk melahirkan manusia-manusia unggul (insan kamil) dengan berpegang teguh kepada al-Qur'an ${ }^{17}$ dan Sunnah -selain nalar juga wahyu- ${ }^{18}$ merupakan suatu bentuk kemutlakan pada ranah teoritisnormatif maupun aplikatif-normatif. Artinya, al-Qur'an dan Sunnah merupakan nilai normatif yang "harus" dijadikan sebagai kerangka yang bermuara pada pandangan hidup, sikap hidup, dan tujuan hidup yang semuanya harus bernafaskan Islam dan dijiwai oleh ajaran-ajaran yang bersumber dari al-Qur'an dan Sunnah.

Di satu sisi juga terdapat minimal ada empat persoalan yang dihadapi pendidikan Islam saat ini. Pertama, minimnya upaya pembaharuan, dan kalaupun toh ada, masih kalah cepat dengan perubahan sosial, politik, dan kemajuan sainstehnologi. Kedua, ilmu-ilmu yang dipelajari dalam institusi pendidikan Islam adalah ilmu-ilmu klasik, sementara ilmu-ilmu modern nyaris taktersentuh sama

\footnotetext{
${ }^{16}$ Syamsul Ma’arif, Revitalisasi Pendidikan Islam, (Yogyakarta: Graha Ilmu, 2007), 16.

${ }^{17}$ Dalam lingkup ini yang dimaksud al-Qur'an adalah kalamullah dan merupakan mu'jizat yang diturunkan kepada nabi Muhammad yang ditulis dalam mushaf, diriwayatkan secara mutawatir, dan membacanya adalah ibadah, lihat. Muhammad Abd al-Azim al-Zarqani, Manahil al-Qur'an fii Ulum al-Qur'an, (Beirut: Dar al-Kutub al-Ilmiyah, 1424 H./2004 M.), 17. Dan secara riil, setiap orang yang menelaah al-Qur'an dan merenungi ayat-ayatnya akan menemukan bahwa secara afirmatif al-Qur'an menjelaskan keesaan Allah dan pluralitas selain Dia. Bahkan al-Qur'an sendiri merupakan referensi yang paling otentik bagi pluralisme. Buktinya, gaya bahasa al-Qur'an yang istimewa membuat setiap kata ayat yang digunakan memiliki kemungkinan makna yang beragam dan memberikan penafsiran yang tidak tunggal. Dan itu menjadi mungkin karena alQur'an diturunkan tidak hanya untuk kaum muslimin saja, akan tetapi untuk semua manusia sekalian alam. Gamal al-Banna, al-Ta'addudiyah fi al-Mujtama' al-Islami, (al-Qahirah: Dar al-Fikr al-Islami, 2001), 12.

${ }^{18}$ Abd. Rachman Assegaf, Filsafat Pendidikan Islam: Paradigma Baru Pendidikan Hadhari Berbasis Integratif-Interkonektif, (Jakarta: Rajawali Pers, 2011), 2. Lihat juga dalam Abuddin Nata, Ilmu Pendidikan Islam, (Jakarta: Kencana, 2010), 36. Juga dalam Tobroni, Pendidikan Islam: Paradigma Teologis, Filosofis dan Spiritualis, (Malang: UMM Press, 2008), 19.
} 
sekali. Ketiga, model pembelajarannya masih menerapkan banking education, di mana guru mendepositokan berbagai macam pengetahuan kepada anak didik. Keempat, orientasi pendidikan Islam cenderung mengutamakan pembentukan 'abd daripada keseimbangan antara 'abdullah dan khalifatullah fil al-ard ${ }^{19}$ Tidak hanya problematika-problematika tersebut yang muncul tapi akan terbentuk pula paradigma superioritas-inferioritas antara satu ilmu terhadap ilmu yang lainnya; antara satu sistem dengan sistem lainnya; atau antara satu budaya dengan budaya lainnya. Ketika paradigma ini telah menjadi bagian dari suatu perspektif, maka sikap truth of claim yang membabi buta terhadap sistem, nilai, atau keyakinan sendiri merupakan suatu sikap yang lazim muncul. Polaritas sikap inilah memberikan efek negatif (merugikan) terhadap sistem kelembagaan pendidikan Islam sendiri yang sedang membutuhkan tatanan sikap insklusifitas, pluralitas dan dialektika-kritis terutama dalam proses pengembangan ilmu pengetahuan Islam (keIslaman).

Kedinamisan sikap yang lebih menghargai perbedaan seperti pada aspek budaya akan memberikan ruang lebar bagi internalitas lembaga pendidikan Islam untuk berkreasi memadukan hal-hal yang positif dari budaya lain. Seperti halnya proses integrasi antara perguruan tinggi Islam dengan pesantren yang dinilai memiliki akar budaya yang sama, sebagai lembaga keilmuan/pendidikan, hanya berbeda dalam lingkungannya. Keduanya diintegrasikan menjadi suatu model perguruan tinggi Islam alternatif -hal ini bisa dilihat seperti Universitas Islam Negeri (UIN) Maulana Malik Ibrahim Malang- yang lebih dinamis dan kritis dalam pengembangan ilmu pengetahuan (khalifah), tapi tetap memiliki sikap tawadhu' dan taqwa yang direpresentasikan dengan polaritas sikap abdullah.

Pada konteks keIndonesiaan yang memiliki beragam suku, ras, dan budaya, sikap kedinamisan tersebut juga akan berpengaruh terhadap pola pengembangan institusi sendiri. Dengan demikian, kajian kritis tentang "Pendidikan Multikulturalisme di Era Modern: Dialektika Kritis Pendidikan Islam Monokotomik" ini sangat menarik untuk dibahas. Sebab selama ini kajian

${ }^{19}$ Babun Suharto, Dari Pesantren Untuk Umat: Reinventing Eksistensi Pesantren di Era Globalisasi, (Surabaya: Imtiyaz, 2011), 3. 
tentang hal ini masih bersifat tawaran konsep yang abstrakta atau filosofisdoktriner, sehingga konsep-konsep tersebut tidak membumi yang hanya bisa diilustrasikan tanpa ada action yang konkrit. Kajian ini juga diharapkan mampu untuk memotori pola pendidikan Islam yang monokotomik untuk lebih menghargai perbedaan yang ada (multikultural) pada konteks keIndonesiaan. Apalagi pendidikan Islam di era sekarang dihadapkan kepada perubahan yang mendasar, terutama mempersiapkan manusia yang nantinya akan berintegrasi dengan masyarakat yang berasal dari berbagai macam latar belakang budaya dan agama serta multi talenta ilmu pengetahuan.

\section{B. Kajian Pustaka}

Pendidikan Islam merupakan pendidikan yang secara khas memiliki ciri Islami, berbeda dengan konsep atau model pendidikan yang lain yang kajiannya lebih menfokuskan pada pemberdayaan umat (insya asy-syay'i ila kamalihi halan fahalan) berdasarkan al-Qur'an dan al-Hadist dalam konteks tertentu. Artinya, kajian pendidikan Islam bukan sekedar menyangkut aspek normatif ajaran Islam, tetapi juga terapannya dalam ragam materi, institusi, budaya atau nilai-nilai, dan dampaknya terhadap pemberdayaan umat. Oleh sebab itu, ada kalangan yang mendefinisikan pendidikan Islam sebagai suatu sistem yang memungkinkan seseorang (peserta didik) dapat mengarahkan kehidupannya sesuai dengan ideologi Islam. Melalui pendekatan ini, ia akan dapat dengan mudah membentuk kehidupan dirinya sesuai dengan nilai-nilai ajaran Islam yang diyakininya. ${ }^{20}$ Juga ada pula yang menekankan pada dua aspek antara lain: pertama, aktivitas pendidikan yang diselenggarakan atau didirikan dengan hasrat dan niat untuk mengejawantahkan ajaran dan nilai-nilai Islam. Kedua, pendidikan Islam adalah sistem pendidikan yang dikembangkan dari dan disemangati oleh ajaran dan nilainilai Islam. ${ }^{21}$ Dari polarisasi ini kemudian terperinci bahwa: ${ }^{22}$ (1). Pendidikan

\footnotetext{
${ }^{20}$ Ramayulis \& Samsul Nizar, Filsafat Pendidikan Islam: Telaah Sistem Pendidikan dan Pemikiran Para Tokohnya, (Jakarta: Kalam Mulia, 2009), 88.

${ }^{21}$ Muhaimin, Rekonstruksi Pendidikan Islam: Dari Paradigma Pengembangan, Manajemen Kelembagaan, Kurikulum Hingga Strategi Pembelajaran, (Jakarta: Rajawali Pers, 2009), 14.

${ }^{22}$ Muhaimin, dkk., Paradigma Pendidikan Islam: Upaya Mengefektifkan Pendidikan Agama Islam di Sekolah, (Bandung: Remaja Rosdakarya, 2004), 29-30.
} 
menurut Islam atau pendidikan Islami, yakni pendidikan yang dipahami dan dikembangkan dari ajaran dan nilai-nilai fundamental yang terkandung dalam sumber dasarnya, yaitu al-Qur'an dan al-Sunnah. Dalam pengertian yang pertama ini, pendidikan Islam dapat berwujud pemikiran dan teori pendidikan yang mendasarkan diri atau dikembangkan dari sumber-sumber dasar tersebut. (2). Pendidikan keislaman atau pendidikan agama Islam, yakni upaya mendidikan agama Islam atau ajaran Islam dan nilai-nilainya agar menjadi pandangan dan sikap hidup seseorang. Dalam pengertian yang kedua ini pendidikan Islam dapat berwujud: a). Segenap kegiatan yang dilakukan seseorang atau suatu lembaga tertentu untuk membantu seorang atau sekelompok peserta didik dalam menanamkan dan/atau menumbuhkembangkan ajaran Islam dan nilai-nilainya; b). Segenap fenomena atau peristiwa perjumpaan antara dua orang atau lebih yang dampaknya ialah tertanamnya dan/atau tumbuh kembangnya ajaran Islam dan nilai-nilainya pada salah satu atau beberapa pihak. (3). Pendidikan dalam Islam, atau proses dan praktek penyelenggaraan pendidikan yang berlangsung dan berkembang dalam sejarah umat Islam. Dalam arti proses bertumbuhkembangnya Islam dan umatnya, baik Islam sebagai agama, ajaran maupun sistem budaya dan peradaban, sejak zaman Nabi Muhammad sampai sekarang. Jadi dalam pengertian ketiga ini istilah pendidikan Islam dapat dipahami sebagai pembudayaan dan pewarisan ajaran agama, budaya dan peradaban umat Islam dari generasi ke generasi sepanjang sejarahnya.

Definisi lain menyebutkan bahwa pendidikan Islam merupakan proses yang mengarahkan manusia pada kehidupan yang baik dan mengangkat derajat kemanusiaannya sesuai dengan kemampuan fitrah $^{23}$ dan kemampuan ajarnya

\footnotetext{
${ }^{23}$ Fitrah berarti potensi dasar manusia, dalam struktur jasmani dan rohani, Allah memberikan seperangkat kemampuan dasar yang memiliki kecendrungan berkembang, yang dalam psikologi di sebut potensialitas atau disposisis, dan menurut aliran psikologi behaviorisme di sebut prepotencereflexes (potensi dasar yang secara otomatis dapat berkembang). Lebih detailnya lagi lihat dalam M. Arifin, Ilmu Pendidikan Islam: Tinjauan Teoritis dan Praktis Berdasarkan Pendekatan Interdisiplinear, (Jakarta: Bumi Aksara, 2003), 42-52. Dalam al-Qur'an disebutkan dalam surat Ar-Rum ayat 30, yang mendeskripsikan hubungan antara makna fitrah dengan agama Allah. Hubungan fitrah dengan "din" tidak konfrontatif, malah sebaliknya saling melengkapi. Dan hubungan ini diperjelas lagi pada surat al-A'raf ayat 172, yang menceritakan tentang drama dialog teologis antara manusia dan Allah.
} 
(pengaruh dari luar). ${ }^{24}$ Pendidikan Islam itu menurut Hasan Langgulung, setidaknya tercakup dalam delapan pengertian yaitu, al-tarbiyah al-diniyah (pendidikan keagamaan), ta'lim al-din (pengajaran agama), al-ta'lim al-diny (pengajaran keagamaan), al-ta'lim al-islamy (pengajaran keIslaman), tarbiyah almuslimin (pendidikan orang-orang Islam), al-tarbiyah fi al-islam (pendidikan dalam Islam) al-tarbiyahinda' al-muslimin (pendidikan di kalangan orang-orang Islam) dan al-tarbiyah al-Islamy (pendidikan Islam). ${ }^{25}$

Para ahli pendidikan Islam bahkan ada yang menyoroti istilah-istilah seperti Al-Ta'diib, Al-Ta'liim dan Al-tarbiyah dari aspek perbedaan antara pendidikan dan pengajaran. Muhammad Athiyyah al-Abrasyi dan Mahmud Yunus menyatakan bahwa istilah Tarbiyah dan Ta'llim dari segi makna istilah maupun aplikasinya memiliki perbedaan mendasar, mengingat dari segi makna istilah tarbiyah berarti mendidik, sementara ta'llim berarti mengajar, dua istilah tersebut secara substansial tidak bisa disamakan. ${ }^{26}$ Imam Baidawi mengatakan bahwa istilah pendidikan (tarbiyah) lebih cocok untuk digunakan dalam pendidikan 1slam. ${ }^{27}$ Sedangkan Abdul Fattah Jalal dari hasil kajiannya berkesimpulan bahwa istilah pengajaran (ta'llim) lebih luas jangkauannya dan lebih umum sifatnya dari pada pendidikan. ${ }^{28}$ Di kalangan penulis Indonesia istilah pendidikan biasanya lebih diarahkan pada pembinaan watak, moral, sikap, dan kepribadian, atau lebih mengarah pada afektif, sementara pengajaran lebih diarahkan pada penguasaan ilmu pengetahuan atau menonjolkan dimensi kognitif dan psikomotor. Kajian lainnya berusaha membandingkan dua istilah di atas dengan istilah ta'dib, sebagaimana dikatakan oleh Syed Naquib al-Attas, yang lahir di Bogor Jawa Barat pada tanggal 5 September 1931 dan kini menjadi warga negara Malaysia, ${ }^{29}$ bahwa dari hasil kajiannya ditemukan bahwa istilah ta'dib lebih tepat untuk

\footnotetext{
${ }^{24}$ Sutrisno, Revolusi Pendidikan di Indonesia: Membedah Metode Dan Tehnik Pendidikan Berbasis Kompetensi, (Yogyakarta: Ar-Ruzz Media, 2005), 125.

${ }^{25}$ Muhaimin, Paradigma Pendidikan Islam ... Op. Cit., 36.

${ }^{26}$ Abd. Halim Soebahar, Wawasan Baru Pendidikan Islam, (Jakarta: Kalam Mulia, 2002), 6.

${ }^{27}$ Ibid., 11.

${ }^{28}$ Ibid., 4.

${ }^{29}$ Ibid., 2. Lebih detailnya lihat Aminullah El-Hady,Pendidikan Berwawasan Islam: Tarbiyah Atau Ta'dib (Tinjauan Terhadap Pandangan Naguib Al-Attas), dalam Jurnal Al-'Adalah Vol. 4, No. 3, Desember 2001, 67-73.
} 
digunakan dalam konteks pendidikan Islam, dan kurang setuju terhadap penggunaan istilah tarbiyah dan ta'lim.

Batasan definitif tersebut terkesan belum terlihatnya penekanan pada nilainilai religius sebagai nilai yang tidak terlepaskan pada diri manusia dan sebagai nilai kontrol. Untuk itu, para ahli ilmuan muslim yang lain, mencoba untuk mendefinisikan terminologi pendidikan dalam perspektif Islam yang secara khusus pada beberapa visi antara lain oleh Syed Sajjad Husain dan Syed Ali Ashraf yang mengatakan bahwa pendidikan Islam merupakan suatu pendidikan yang melatih perasaan peserta didik dengan cara begitu rupa sehingga dalam sikap hidup, tindakan, keputusan, dan pendekatan mereka terhadap segala jenis pengetahuan, mereka dipengaruhi sekali oleh nilai spiritual dan sangat sadar akan nilai etis Islam. ${ }^{30}$ Begitu pula M. Arifin memandang bahwa pendidikan Islam adalah suatu proses sistem pendidikan yang mencakup seluruh aspek kehidupan yang dibutuhkan oleh hamba Allah (peserta didik) dengan berpedoman pada ajaran Islam. ${ }^{31}$

Dengan demikian, pendidikan Islam bisa dikatakan sebagai suatu sistem pendidikan yang dikembangkan dari ajaran Islam yang bersumber langsung dari al-Qur'an, al-Hadist, dan ijma' ulama' dan sekaligus untuk mengejawantahkan ajaran-ajaran Islam, sehingga dalam sikap hidup, tindakan, keputusan, dan pendekatan peserta didik terhadap segala jenis pengetahuan dapat dipengaruhi dengan nilai-nilai spiritual Islam dan secara sadar akan menerapkan dalam perilaku kehidupannya. Dengan pola batasan tersebut memberikan ruang cakupan yang luas bahwa pendidikan Islam adalah rangkaian proses sistematis, terencana dan komprehensif dalam upaya mentransfer nilai-nilai kepada peserta didik, mengembangkan potensi yang ada pada diri peserta didik sehingga mampu melaksanakan tugasnya dimuka bumi dengan sebaik-baiknya, sesuai dengan nilainilai Ilahiyah yang didasarkan pada ajaran agama (al-Qur'an dan al-Hadist) pada semua dimensi kehidupannya.

\footnotetext{
${ }^{30}$ Syed Sajjad Husaian \& Syed Ali Ashraf, Krisis Pendidikan Islam, Peterj.: Rahmani Astuti, (Bandung: Risalah, 1986), 2.

${ }^{31}$ M. Arifin, Ilmu Pendidikan Islam, 29.
} 


\section{Metode Penelitian}

Penelitian ini menggunakan metode analisis deskriptif yakni suatu metode yang menganalisis data suatu objek kajian, kemudian mendeksripsikannya sesuai hasil analisis data tersebut.

\section{Pembahasan}

Ada kalangan yang secara lugas menyatakan bahwa pendidikan Islam yang ideal adalah pendidikan Islam yang dapat menunjang proses pembentukan manusia menjadi manusia yang demokratis, pluralis dan menekankan penghayatan hidup serta refleksi untuk menjadi manusia yang utuh, yaitu generasi muda yang tidak hanya pandai tetapi juga bermoral dan etis, dapat hidup dalam suasana demokratis satu dengan lain, dan menghormati hak orang lain. Artinya, pada diri manusia -baca output dan outcome dari pendidikan Islammuncul suatu tatanan kepribadian yang integral dan selaras-serasi antara nafas spirit ajaran Islam dengan pola perilaku yang terejawantahkan dalam kehidupannya. Termasuk dalam konteks ini pola kedewasaan dan kearifan dalam melihat kemajemukan tradisi dan budaya serta keyakinan antar beragama. ${ }^{32}$ Pada ranah inilah terbentuk konstruksi struktur pendidikan multikultural yang mencoba untuk memberikan ruang kesadaran tentang kemajemukan budaya.

Dengan demikian, pendidikan multikultural diharapkan bisa membentuk suatu tatanan paradigma kearifan terhadap kemajemukan budaya yang mengedepankan toleransi antar perbedaan yang ada di lingkaran realitas keindonesiaan. Walaupun secara faktual, pendidikan (Islam) multikultural masih bisa ditengarai hanya merefleksikan dan menggemakan stereotip dan prasangka antarkelompok yang sudah terbentuk dan beredar dalam masyarakat, tidak

\footnotetext{
${ }^{32} \mathrm{Pada}$ arus ini terdapat struktur kesepahaman dalam perbedaan antara keyakinan beragama yang anatominya bersifat dialogis. Oleh sebab itu, paham pluralisme sangat menghendaki terjadinya dialog antaragama, dan dengan dialog agama memungkinkan antara satu agama terhadap agama lain untuk mencoba memahami cara baru yang mendalam mengenai bagaimana Tuhan mempunyai jalan penyelamatan. Pengalaman ini sangat penting untuk memperkaya pengalaman antar iman, sebagai pintu masuk ke dalam dialog teologis. Inilah sebuah teologi yang menurut Wilfred C. Smith disebut dengan istilah world theology (teologi dunia). Lihat detailnya dalam Wilfred C. Smith, Toward Theology: Faith and the Comparative History of Religion, (London: The Macmillan Press, 1981), 187. Sedangkan oleh John Hick menyebutnya sebagai global theology (teologi global). John Hick, Philosophy of Religion, (New Delhi: Prentice Hall, 1980), 8. Kemudian teologi tersebut belakangan ini lebih dikenal dengan sebutan teologi pluralisme.
} 
berusaha menetralisisir dan menghilangkanya sebagai suatu kelaziman di atas lingkaran sosio-budaya yang terkonstruks di masyarakat. Riskannya, lembaga pendidikan (Islam) turut memperuncing persoalan tersebut dengan memberikan ruang lebar terhadap tumbuhkembangnya prasangka dan juga mengeskalasi ketegangan antarkelompok melalui fregmentasi penyampaiaan pendidikan agama, isi kurikulum yang etnosentris, dan dinamika relasi sosial antar lembaga pendidikan yang segregatif.

Oleh sebab itulah, pendidikan multikultural perlu untuk mengelaborasi elemen-elemen kemajemukan budaya menjadi konstruksi kearifan antar golongan atau komunitas -baca budaya. Hal ini dimaksudkan sebagai upaya untuk membangun struktur masyarakat yang lebih beradab, harmonis, dan sejahtera dengan tetap menghargai khazanah perbedaan budaya. Keterbukaan pola pikir terhadap realitas kebudayaan akan lebih memperlebar cakrawala keharmonisan antar kelompok budaya, sehingga menjadi suatu kelaziman jika segregasi lembaga pendidikan berdasarkan satu komunitas budaya atau kepemelukan agama juga ikut memperuncing prasangka dan proses demonisasi antara satu kelompok dengan kelompok lainya, baik secara langsung maupun atau tidak langsung. Segregasi yang demikian inilah memobilisasi kemunculan term "yang lain" (the other) sebagai versus keakuan (the self), sehingga yang terpampang adalah dua faktasitas yang saling berlawanan dan sulit untuk dicari titik temunya.

Adanya konstruks pendidikan (Islam) multikulturalisme membawa pada tatanan baru struktur pendidikan yang memiliki karakteristik pluralis dan membawa nilai-nilai kearifan dalam perbedaan budaya. Konstruks pendidikan ini yang diyakini akan menyokong terbentuknya masyarakat multikulturalisme dan pluralisme; di mana seluruh masyarakat dengan segala unsurnya dituntut untuk saling tergantung dan menanggung nasib secara bersama-sama demi terciptanya perdamaian abadi. Salah satu bagian penting dari konsekuensi tata kehidupan global yang ditandai kemajemukan etnis, budaya, dan agama tersebut, adalah membangun dan menumbuhkan kembali teologi global -meminjam istilah dari John Hick- atau lazim dikatakan sebagai teologi pluralisme. Substansi tata konsep 
ini adalah penumbuhan kesadaran etik terhadap kemajemukan budaya ataupun agama di dalam kehidupan manusia.

Sedangkan Islam sendiri memiliki posisi yang sangat jelas terhadap keberagaman budaya dan juga terhadap perbedaan agama. Ia tidak menolak adanya pluralitas budaya ataupun agama, bahkan Islam memberikan kerangka yang bersifat etis dan positif dengan platform yang sesuai dengan ajaran-ajaran normatif Islam. Pada ranah ini, sikap Islam tercermin dalam beberapa ayat alQur'an yang secara eksplisit mengakui kenyataan tersebut, ${ }^{33}$ bahkan ia sendiri tidak menentangnya karena kemajemukan tersebut merupakan sunnahtullah. Dari kerangka inilah dapat terbaca sisi korelasi dan relevansi antara pendidikan (Islam) multikultural dengan teologi sebagai payung normatis-etiknya.

Faktanya yang perlu disadari adalah nilai-nilai normatif apapun yang terkonstruksi dan disampaikan oleh pendidikan Islam pada subjek dan objek didik tidak lepas dari peran teologi yang menjadi payung normatif-etiknya dan ia sendiri merupakan inti agama yang semua struktur anatomi tujuan pendidikan tidak lepas dari acuan dasar tersebut. Dalam pandangan penulis, mungkin ranah inilah indoktrinasi bisa dilakukan dengan latar legitimasi normatif dari ajaranajaran Islam, sehingga keutuhan pesan ajaran Islam tentang kemajemukan budaya dalam realitas kemanusiaan dapat tersampaikan.

Oleh karena itu, bila ada keinginan untuk merekonstruksi pendidikan (Islam) multikulturalisme dalam arti nilai yang akan disampaikan dalam pendidikan apalagi dalam konteks kemajemukan budaya, maka bidang teologi inilah yang perlu mendapatkan perhatian sebagai entitas utama yang perlu direkonstruksi atau bahkan didekonstruksi. Oleh karena selama ini yang muncul adalah bentuk pemahaman teologi yang masih berkutat pada masalah truth claim (klaim kebenaran) untuk dirinya sendiri, sehingga nilai-nilai yang ditimbulkan oleh pihak lain di luar agamanya adalah salah. Teologi yang demikian memandang dirinya sebagai komunitas yang mewakili kebenaran dari Tuhan, sehingga ia lebih memandang rendah komunitas di luar dirinya.

\footnotetext{
${ }^{33}$ Syamsul Arifin \&Ahmad Barizi, Paradigma Pendidikan Berbasis Pluralisme dan Demokrasi: Rekonstruksi dan Aktualisasi Tradisi Ikhtilaf dalam Islam,(Malang: UMM Press, 2001), 2.
} 
Banyak kalangan ketika melihat masalah tersebut menyesalkan dan juga mencibir sebagai sesuatu yang tidak berguna. Sebab kalangan tersebut menilai bahwa dalam diskusi teologis yang menitikberatkan pada fenomena truth claim mengeliminir aspek-aspek fundamental agama yang ada. Jika truth claim hanya terbatas pada aspek ontologism-metafisis, tak perlu dirisaukan karena hal ini sedah menjadi keharusan (a must) yang mutlak dipenuhi. Namun yang terjadi sebaliknya ia lebih memasuki wilayah sosial-budaya dan juga politik yang praktisempiris; dan ini yang sering menimbulkan kericuhan diantara umat-umat beragama sepanjang zaman, karena ia dipahami secara mentah dan emosional. Hal ini memunculkan kesan bahwa agama dinggap sebagai "momok" yang ditakuti, ketimbang sebagai agama yang perlu dihormati karena konsepsi-konsepsinya yang luhur dalam memecahkan kesulitan manusia sekarang. ${ }^{34}$

Pada ranah kemajemukan budaya, fakta teologi juga turut mewarnai konstruksi kearifan budaya. Konsekuensinya yang perlu disikapi adalah cakrawala persepsi dan konsepsi yang ada dalam diri subjek dan objek pendidikan yang digunakan sebagai kacamata untuk melihat kesatuan asal-muasal budaya seluruh umat manusia. Artinya, dalam pendidikan multikultural perlu ada suatu paradigma yang mampu menghargai -atau bisa juga dibaca mengintegrasikan dua entitasperbedaan tata nilai dan norma dalam budaya. Paradigma tersebut adalah paradigma monokotomik yaitu suatu paradigma yang melihat satu kesatuan seluruh ilmu pengetahuan, nilai, norma dan entitas ajaran agama lainnya.

Konstruksi ilmu pengetahuan yang lahir dari rahim epistemologi integratif akan mendorong pendidikan (Islam) multikultural lebih menemukan titik kulminasinya sebagai gerbang ilmu pengetahuan terutama tentang ilmu pengetahuan keIslaman yang komprehensif-solutif dengan frame kearifan kebudayaan. Sehingga hal ini berimbas pada proses konversi kelembagaan pendidikan yang lebih memfokuskan pada pengembangan ilmu pengetahuan terutama dalam membangun kesadaran kemajemukan kebudayaan. Pada arus inilah fakta yang lebih urgen adalah proses transformasi kelembagaan secara

\footnotetext{
${ }^{34}$ William C. Chittic, The Islamic Concept of Human Perfection, (T.kt.:The World \& I., 1991), 499
} 
institusional seperti yang dikatakan oleh Amin Abdullah bahwa pengembangan dan konversi IAIN ke UIN adalah proyek keilmuan. Proyek pengembangan wawasan keilmuan dan perubahan tata pikir keilmuan yang bernafaskan keagamaan transformatif. Bukan berubah asal berubah, bukan sekedar ikut-ikutan, bukan pula sekedar proyek fisik. Konversi dari IAIN ke UIN adalah momentum untuk membenahi dan menyembuhkan "luka-luka dualisme" keilmuan umum dan agama yang makin hari makin menyakitkan. ${ }^{35}$

Dengan kerangka pengembangan keilmuan dalam melakukan konversi institusi, maka pendidikan Islam secara umum memiliki kesempatan untuk membangun metodologi keilmuan yang lebih integratif dalam mengkonstruks anatomi sistem pendidikannya. Sistem pendidikan yang integral melihat realitas (being) -yang bersifat metafisis dan fisika- tetap pada kerangka kesatuan ontologik dengan epistemologik-metodologik transendental. Artinya, sistem pendidikan Islam yang demikian membangun anatomi atau kerangka pendidikannya tetap pada koridor ontos-metafisis dengan epistemologi scientificparadigm atau naturalisticparadigm yang integral tanpa ada dikotomi antara yang transendental dan profan; agama dan umum (non agama).

Pada satu sisi pula konstruksi sistem pendidikan (Islam) multikultual berparadigma monokotomik lebih memprioritaskan pada kesatuan platform, sehingga ia lebih menghargai perbedaan sebagai suatu tatanan sunnahtullah daripada memunculkan entitas "yang lain" (the other). Dengan demikian, pola integritas inilebih mampu memberikan kepastian pada susunan sistem pendidikan Islam terutama pada formulasi isi dan tujuan dari pendidikan Islam sendiri. ${ }^{36}$ Walaupun demikian, kajian-kajian kritis yang bersifat analitis-diagnostik terhadap sistem pendidikan (Islam) multikultural tetap perlu dilakukan sebagai upaya penyeimbang untuk menemukan bangunan sistem pendidikan yang lebih baik. Telebih lagi secara faktual, posisional pemikiran pendidikan Islam masih sebagai aspek yang terlantarkan dalam kajian keIslaman yang ada sekarang ini. ${ }^{37}$

\footnotetext{
${ }^{35}$ Amin Abdullah, Islamic Studies di Perguruan Tinggi: Pendekatan IntegratifInterkonektif, (Yogyakarta: Pustaka Pelajar, 2006), 399.

${ }^{36}$ Sukarji \& Umiarso, Manajemen dalam Pendidikan ... Op. Cit., 46-47.

${ }^{37}$ Mahmud Arif, Pendidikan Islam Transformatif, (Yogyakarta: LKiS, 2008), 8.
} 
Menurut pandangan penulis, polarisasi dikotomi keilmuan turut serta membingkai paradigma pendidikan (Islam) dalam melihat konstruksi entitas yang lain (the other). Oleh sebab itu, terhadap dikotomi keilmuan yang ada pada mainstream umat Islam, memang perlu ada salah satu upaya untuk mendombrak tatanan tersebut. Dengan meletakkan epistemologi dan teori sistem pendidikan yang bersifat sangat mendasar seakan-akan menjadi pilihan utama yang tidak bisa dihindarkan sebagai suatu alternatif-solutif. Di mana pada aspek epistemologi, umat Islam agar lebih tampil berani dalam mengembangkan kerangka pengetahuan mereka yang ada pada saat ini untuk diartikulasikan sesuai dengan spirit monotoisme. Dengan demikian, perlu ada kerangka konseptual terhadap ilmu pengetahuan yang dikembangkan dengan berbagai model dan metode yang sesuai tinjauan dunia mereka yang berpijak -atau mencerminkan- nilai dan norma budaya mereka yang tertuang dalam al-Qur'an dan al-Hadist. Pola yang bersifat aplikatif-konseptual ini yang turut andil dalam menciptakan teori sistem pendidikan yang memadukan antara sistem pendidikan yang bercorak analitiskritis dan sekuler yang direpresentasikan oleh sistem pendidikan umum- dengan sistem pendidikan yang bercorak dogmatis-skriptualis dan doktriner-sistem pendidikan yang direpresentasikan oleh pendidikan agama.

Dari deskripsi tersebut bahwa integralisasi ontologik yang bergulir pada keterpaduan epistemologik memiliki implikasi yang luas pada konstruks anatomi sistem pendidikan Islam. Maka wajar apabila pendidikan tinggi Islam seperti halnya UIN Sunan Kalijaga ataupun UIN Maulana Malik Ibrahim Malang perlu membentuk paradigma penyatuan (integralistik) seperti konsep atau bangunan ilmu yang telah digelontorkannya yaitu Jaring Laba-Laba Ilmu oleh Amin Abdullah atau Pohon Ilmu oleh Imam Suprayogo. Hal ini, menyetir pandangan Amin Abdullah, paradigma keilmuan baru yang menyatukan, bukan sekedar menggabungkan wahyu Tuhan dan temuan pikiran manusia (ilmu-ilmu holistikintegralistik), itu tidak akan berakibat mengecilkan peran Tuhan (sekulerisme) atau mengucilkan manusia sehingga teraleniasi dari dirinya sendiri, dari 
masyarakat sekitar, dan lingkungan hidup sekitarnya. ${ }^{38}$ Artinya, harmonisasi keterpaduan inilah yang dikatakan sebagai pembingkaian epistemologi ilahiyah yaitu ketika manusia merenung, mengkaji, dan mengkritisi kebesaran-Nya, maka akan tersikap hakikat uluhiyah yang mutlak, azali, dan abadi. Pada sisi yang lain, di bawah bayang-bayang tersebut, manusia juga dapat memandang hakikat kehambaan yang terbatas, baru, dan fana. Artinya, dua sisi tersebut akan memberikan harmonisasi perpaduan antara sisi ketuhanan (wahyu) dan kemanusiaan (akal) yang mengintegrasikan antara iman, ilmu dan amal. Dengan dasar ini, maka pendidikan Islam mampu mengembangkan tujuan pendidikan lebih membumi dengan tetap berpijak pada sisi kesatuan yang transendental. ${ }^{39}$ Pada kerangka inilah terdapat fakta yang menarik dari Ahmad Tafsir, landasan filosofis untuk pengembangan ilmu pendidikan Islami adalah keyakinan bahwa semua pengetahuan datang dari Tuhan baik pengetahuan sains, pengetahuan filsafat yang rasional maupun pengetahuan suprarasional. ${ }^{40}$

Sebagai sebuah ideologi, multikulturalisme adalah pandangan bahwa setiap kebudayaan memiliki nilai dan kedudukan yang sama dengan setiap kebudayaan lain, sehingga setiap kebudayaan berhak mendapat tempat sebagaimana kebudayaan lainnya. ${ }^{41}$ Artinya, pandangan yang mengedepankan posisional egaliter pada semua sistem kebudayaan, sehingga pandangan ini mampu menghilangkan superioritas-inferioritas antara satu kebudayaan dengan kebudayaan lainnya. Pandangan ini memberikan efek positif terhadap bangunan kemasyarakatan yang ditandai dengan perilaku atau sikap saling menghargai dan menghormati dalam perbedaan, open minded, dan saling memahami serta memberi pengertian antar anggota masyarakat. Faktasitas inilah yang menjadi embrionikal dari masyarakat multikultural yang secara sederhana ditandai oleh, meminjam konklusi dari Robert W. Hefner dikatakan, sejauhmana masyarakat

\footnotetext{
${ }^{38}$ Amin Abdullah, Islamic Studies di Perguruan, 104-105.

${ }^{39}$ Sukarji \& Umiarso, Manajemen dalam Pendidikan ., 45.

${ }^{40}$ Ahmad Tafsir, Ilmu Pendidikan Islami ., 309.

${ }^{41}$ Zakiyuddin Baidhawy, Pendidikan Agama Berwawasan Multikultural, (Jakarta: Erlangga, 2007), 4.
} 
mampu memenuhi norma-norma keadilan, kebebasan individu, dan demokrasi permusyawaratan (deliberatif). ${ }^{42}$

Namun ada pula yang menyatakan bahwa masyarakat multikultural merupakan masyarakat yang terdiri dari "dua atau lebih elemen atau tatanan sosial yang hidup berdampingan, namun tanpa membaur, dalam satu unit politik. ${ }^{43}$ Tatanan masyarakat ini secara afirmatif-deskriptif memunculkan asumsi tentang relasi egaliter yang dibangun dengan kesadaran dan kesediaan untuk menerima perbedaan, sehingga nilai subordinat dan dominan group tidak ada, karena setiap kelompok atau kebudayaan mempunyai kesempatan yang sama untuk mengekspresikan diri, hidup berdampingan, dan bekerjasama dengan kelompok yang lain. Perbedaan yang ada tersebut membantu untuk menunjang kreativitas anggota masyarakat dalam menciptakan tatanan kesatuan dalam merangkum kemajemukan kebudayaan.

Dari konsep tersebut sangat jelas anatomi dari masyarakat multikultural memiliki karakteristik yang sangat menarik, antara lain: kemajemukan nilai (kebudayaan), memiliki kesadaran untuk mengembangkan semangat kerukunan, mengagungkan hidup tolerasi serta memiliki kebanggaan terhadap kemajemukan tersebut. Dengan demikian, masyarakat ini tersusun atas berbagai budaya yang menjadi sumber nilai bagi terpeliharanya kestabilan kehidupan masyarakat pendukungnya. Keragaman budaya tersebut berfungsi untuk mempertahankan dasar identitas diri dan integrasi sosial masyarakatnya. ${ }^{44}$ Di sisi yang lain, sumber daya manusia yang ada di dalamnya memiliki pandangan menjunjung tinggi sikap saling menghargai (mutual respect); di mana sikap ini mendudukan manusia dalam relasi kesetaraan, tidak ada superioritas maupun inferioritas. ${ }^{45}$ Islam pada kerangka ini secara normatif menyatakan bahwa manusia diciptakan bersuku-suku

\footnotetext{
${ }^{42}$ Robert W. Hefner, Introduction: Multiculturalism and Citizenship in Malaysia, Singapore, and Indonesia, dalam Robert W. Hefner (Edit.), The Politics of Multiculturalism: Pluralism and Citizenship in Malaysia, Singapore, and Indonesia, (Honolulu: University of Hawai'i Press, 2001), 3.

${ }^{43}$ Ibid., 4.

${ }^{44}$ Bagja Waluya, Sosiologi: Menyelami Fenomena Sosial di Masyarakat, (Jakarta: PT. Setia Purna, 2007), 105.

${ }^{45}$ Zakiyuddin Baidhawy, Pendidikan Agama Berwawasan ., 83.
} 
dengan derajat yang sama kecuali dalam aspek ketaqwaannya; ${ }^{46}$ dan dianjurkan untuk tolong menolong dalam hal kebaikan dan ketaqwaan ${ }^{47}$ tanpa melihat suku, ras, maupun golongan tertentu.

Berangkat dari salah satu faktasitas tersebut, maka pendidikan Islam perlu untuk terus menerus melakukan pembenahan institusi dengan mengkonversikan kelembagaannya menjadi institusi yang lebih menjangkau luas cakupan disiplin keilmuannya. Haidar Putra Daulay mengidentifikasi beberapa latar yang mendorong perubahan institusi kelembagaan seperti metamorfosis kelembagaan STAIN atau IAIN menjadi UIN, antara lain: 1). Integrasi antara bidang ilmu agama dengan bidang ilmu umum (perennial knowledge dengan accquined knowledge) sehingga antara kedua ilmu menyatu, sehingga tidak lagi terjadi dikotomi; 2). Berubahnya status madrasah sebagai sekolah yang berciri khas agama Islam. Sehingga tamatan Madrasah Aliyah lebih dipersipakan untuk memasuki universitas. Oleh karena itu apa yang diajarkan di madrasah sama dengan dengan apa yang diajarkan di sekolah; dan 3). Alumni UIN lebih terbuka kesempatan untuk mobilitas vertikal dibandingkan alumni IAIN dan lebih beragam lapangan kerja yang bisa dimasuki. ${ }^{48}$

Faktualnya, metamorfosis intitusi kelembagaan pendidikan Islam tersebut menginginkan output yang menyelaraskan dan mengintegrasikan antara duniawi dan ukhrowi; antara yang profan dengan yang transendental; dan antara ilmu pengetahuan agama dengan ilmu pengetahuan umum. Sebut saja salah satu konsep Jaring Laba-Laba Ilmu yang dicetuskan oleh Amin Abdullah, ${ }^{49}$ mengambarkan "manusia ideal" beragama (Islam) yang kompeten dalam membidangi dan menganalisa isu-isu mengenai dinamika sosial, kemanusiaan dan keagamaan di era modern dan pasca modern dengan dikuasainya berbagai

\footnotetext{
${ }^{46}$ QS. Al-Hujaraat: 49.

${ }^{47}$ QS. Al-Maidaah: 2.

${ }^{48}$ Haidar Putra Daulay, Sejarah Pertumbuhan dan Pembaruan Pendidikan Islam di Indonesia,(Jakarta: Kencana Prenada Media Group, 2009), 140-141.

${ }^{49}$ Amin Abdullah, Islamic Studies di Perguruan, 104-105. Lihat juga dalam tulisan Nurul Anam, Desekularistik-Implementatif Sebagai Paradigma Baru Masa Depan Pendidikan UIN: Dari Islamisasi Sins sampai Optimalisasi Jaring Laba-Laba Keilmuan TeoantroposentrikIntegralistik dengan Learning Pyramid Oriented, dalam The $9^{\text {th }}$ Annual Conference on Islamic Studies (ACIS), di Surakarta pada tanggal 2-5 Nopember 2009.
} 
pendekatan baru yang diberikan oleh ilmu-ilmu alam (natural science), ilmu-ilmu sosial (social science) dan humaniora (humanities) kontemporer. Di atas segalanya, dalam setiap langkah yang ditempuh, selalu dibarengi landasan etikamoral keagamaan objektif dan kokoh, karena keberadaan al-Qur'an dan asSunnah yang dimaknai secara baru (hermeneuties) selalu menjadi landasan pijak pandangan hidup (weltanschauung) keagamaan manusia yang menyatu dalam satu tarikan nafas keilmuan dan keagamaan. Semua itu diabdikan untuk kesejahteraan manusia secara bersama-sama tanpa pandang latar belakang etnisitas, agama, ras maupun golongan. Bisa dikatakan, semua itu dilakukan untuk kepentingan kemajuan dan pengembangan masyarakat multikultural seperti Indonesia.

Oleh sebab itu, sebagai masyarakat Muslim di Indonesia, perkembangan kelembagaan serta posisional kelembagaan pendidikan Islam seperti madrasah ataupun pesantren terebih STAIN, IAIN, ataupun UIN tersebut tentu patut dihargai serta diapresiasi sebagai suatu bentuk usaha dalam membangun peradaban bangsa yang bermartabat tinggi dan memiliki dasar moralitas yang kuat. Namun, tidak hanya pada aspek institusi kelembagaannya, wacana-wacana atau gagasan-gagasan serta konsep-konsep keilmuan yang ditawarkannya membingkai "kepentingan" yang lebih luas untuk menciptakan tatanan kehidupan sosial yang lebih menghargai unsur perbedaan sebagai bentuk dari sunnahtullah. Apalagi tawarannya tersebut jauh lebih moderat dari sebelumnya yang terkadang masih terperangkap faktasitas skriptualis; yang oleh Muhammad Abed al-Jabiri, pemikir asal Maroko dikatakan sebagai epistemologi bayani, atau dalam bahasa M. Amin Abdullah disebut dengan hadharah an-nashsh (budaya agama yang semata-mata mengacu pada teks), sehingga pendidikan hanya semata-mata bergelut dengan setumpuk teks-teks keagamaan yang sebagian besar berbicara tentang permasalahan fikih an sich. Perkembangan yang demikian masif ini merupakan suatu upaya konstruktif yang berupa gerakan transformasi institusi kelembagaan pendidikan Islam menjadi gerakan pembaharuan untuk kemajuan peradaban Islam sendiri. 


\section{E. Kesimpulan}

Di era modren, pendidikan (Islam) multikltural dengan paradigma monokotomik sebagai suatu keniscayaan sebab ia diyakini lebih mampu untuk memberikan ruang yang lebar bagi perkembangan kesadaran kemajemukan realitas sosial (bahkan pada konteks agama) serta bisa menjawab dan menumbuhkembangkan sikap egaliter terhadap kebudayaan yang lain. Basis utama pendidikan Islam monokotomik ini adalah pengintegrasian dua entitas yaitu ilmu agama dan ilmu umum yang selama ini terpisah secara diametral. Dengan pola ini, maka kerangka pendidikannya tetap pada koridor ontos-metafisis dengan epistemologi scientificparadigm atau naturalisticparadigm yang integral tanpa ada dikotomi antara yang transendental dan profan; agama dan umum (non agama). Kerangka inilah yang mampu memberikan kepastian pada susunan sistem pendidikan Islam yang ideal memunculkan kesadaran kemajemukan realitas sosial-budaya dan melestarikan sikap egaliter terhadap kebudayaan yang lain sebagai tonggak utama masyarakat multikultural. 


\section{Daftar Pustaka}

Abd. Halim Soebahar, Wawasan Baru Pendidikan Islam, (Jakarta: Kalam Mulia, 2002).

Abd. Rachman Assegaf, Filsafat Pendidikan Islam: Paradigma Baru Pendidikan Hadhari Berbasis Integratif-Interkonektif, (Jakarta: Rajawali Pers, 2011).

Abu Luwis al-Yasu'I, al-Munjid Fi al-Lughah Wa al-Munjid Fi al-A'lam, (Bairut: Dar al-Masyriq, $\mathrm{tt}$ ).

Abuddin Nata, Ilmu Pendidikan Islam, (Jakarta: Kencana, 2010).

Ahmad Musthafa al-Maraghy, Tafsir al-Maraghy, Peterj.: Bahrun Abubakar, (Semarang: Toha Putra, 1985).

Ahmad Tafsir, Ilmu Pendidikan Islami, (Bandung: Remaja Rosdakarya, 2012).

Amin Abdullah, Islamic Studies di Perguruan Tinggi: Pendekatan IntegratifInterkonektif, (Yogyakarta: Pustaka Pelajar, 2006).

Aminullah El-Hady, Pendidikan Berwawasan Islam: Tarbiyah Atau Ta'dib (Tinjauan Terhadap Pandangan Naguib Al-Attas), dalam Jurnal Al'Adalah Vol. 4, No. 3, Desember 2001.

Babun Suharto, Dari Pesantren Untuk Umat: Reinventing Eksistensi Pesantren di Era Globalisasi, (Surabaya: Imtiyaz, 2011).

Bagja Waluya, Sosiologi: Menyelami Fenomena Sosial di Masyarakat, (Jakarta: PT. Setia Purna, 2007).

Bruce A. Kimball, The Liberal Arts Tradition Documentary History, (Maryland: University Press of America, 2010).

Charlene Tan, Islamic Education and Indoctrination: The Case in Indonesia, (New York: Routledge, 2011).

Dagobert D. Runes (Edit.), The Dictionary of Philosophy, (New York: Philosophical Library, t. th.).

Gamal al-Banna, al-Ta'addudiyah fi al-Mujtama' al-Islami, (al-Qahirah: Dar alFikr al-Islami, 2001).

Haidar Putra Daulay, Sejarah Pertumbuhan dan Pembaruan Pendidikan Islam di Indonesia,(Jakarta: Kencana Prenada Media Group, 2009).

Hamka, Tafsir al-Azhar, Jilid XXX, (Jakarta: Pustaka Panjimas, 1988).

Harun Nasution, Islam Ditinjau dari Berbagai Aspeknya, (Jakarta: UI Press, 1979).

Hasan Langgulung, Pendidikan dan Peradaban Islam,(Jakarta: al-Husna, 1985).

John Hick, Philosophy of Religion, (New Delhi: Prentice Hall, 1980).

John Walbridge, God and Logic in Islam:The Caliphate of Reason, (Cambridge: Cambrige University Press, 2011). 